\title{
Globalization and Cross-Border Labor Organizing
}

\section{Ralph Armbruster, University of California, Riverside}

The globalization of the world economy has opened up new possibilities for cross -border labor organizing. In fact, several U.S. unions are working together with unions from Mexico, Honduras, Guatemala, the Dominican Republic, Japan, South Korea, and many European nations. For example, over the last several years, UNITE (Union of Needletrades, Industrial, and Textile Employees), the AFL-CIO, and the international garment workers trade secretariat have worked directly with maquiladora workers in Honduras and the Dominican Republic. These efforts led to the formation of several labor unions and the first contracts ever negotiated in the maquiladoras in the Dominican Republic. In addition, labor rights and solidarity organizations, like the Campaign for Labor Rights, Witness for Peace, and the US/Guatemala Labor Education Project (US/GLEP), along with many other groups, have also played key roles in the formation of maquiladora unions in Nicaragua and Guatemala.

Two recent and successful cross -border labor organizing campaigns involved Phillips Van-Heusen (PVH) and the GAP (Armbruster, 1997; Pattee, 1996). These two U.S.based garment manufacturers "contract out" production - mostly shirts and jeans - to factories in Guatemala and El Salvador respectively. Both companies employ mostly young women who work very long hours and who earn far below the prevailing "living wage." These conditions, along with dehumanizing treatment from supervisors, led PVH and GAP workers to begin organizing. However, both companies responded with repressive tactics that included mass firings, death threats, severance payments, and involuntary dismissals. Both companies also threatened to cut their contracts with their suppliers and move to different locations. Yet, these women workers continued organizing and eventually won. After seven years, the PVH workers' union was recognized and contract negotiations are currently underway. The GAP s igned a historic independent monitoring agreement with labor and human rights groups who oversee the company's contractors in Central America.

These victories contradict the theoretical literature, including some variants of the worldsystem perspective, on cross-border labor organizing. Previous research indicates that there are three main forces which limit the possibility of cross-border organizing. First, the globalization perspective suggests the rapid dispersion of production, especially in the highly mobile garment industry, can undermine cross-border organizing between labor unions in two different nations. Second, repressive and corporatist state-labor relationships often produce small and weak labor movements. Under these conditions the establishment of cross-border labor linkages is extremely difficult. The third factor limiting cross-border labor organizing involves the long history of the AFL-CIO in Latin America, Africa, and Asia. For nearly fifty years the AFL-CIO's foreign affiliates undermined and divided labor unions all over the world. These machinations generated suspicion of the AFL-CIO and restricted cross-border organizing between U.S. unions and unions in Latin America, Asia, and Africa. 
Interestingly, these three factors were all present in the PVH and GAP campaigns. The existing literature would predict that cross-border labor organizing that effectively targeted two highly mobile garment manufacturers in nations noted for their violent history of labor repression, and which involved the AFL-CIO and U.S.-based labor rights groups such as US/GLEP and the National Labor Committee (NLC), would be virtually impossible. Given these overwhelming odds, how did the PVH and GAP workers achieve their victories?

In the case of Phillips Van-Heusen, the PVH workers obtained critical support from the garment workers trade secretariat. Second, US/GLEP and NLC used trade pressure and provided legal assistance and media coverage to the PVH and GAP workers. Third, a new, strategic organizing model and loc al union activism were critical elements of the PVH campaign. Fourth, students, religious groups, and Central American solidarity organizations from the United States and Canada leafleted retailers (like J. C. Penney and Wal-Mart) who sold PVH and GAP products and raised consumer awareness of these issues. Fifth, the PVH and GAP workers and their international network of supporters targeted the "socially responsible" image of both companies. Interestingly, PVH and the GAP both have corporate codes of conduct, establishing minimal standards that their overseas suppliers must abide by, but neither company ever informed their workers of these codes. Public scrutiny and direct attacks on these companies' carefully crafted image was particularly effective in limiting capital flight. The combination of these elements produced two stunning victories for women garment workers in Guatemala and El Salvador.

These two cases illustrate the potential of cross-border labor organizing and the limitations of the existing literature. However, there have also been many unsuccessful cases of cross-border organizing. For instance, the United Auto Workers (UAW) has not yet developed ties with the Ford Democratic Workers Movement in Mexico, although UAW Local 879 and UAW Region 1A have done so. Thus the current outlook for the development of a global labor movement is mixed. Renewed labor militancy in the United States, the closing of the AFL-CIO's foreign affiliates, harsh working conditions in many developing nations, and the emergence of consumer campaigns that attack the public image of multinational corporations have generated exciting cross-border organizing campaigns. However, bureaucratic union structures, corporatist labor movements, and other factors still limit cross-border organizing.

Cross-border organizing is very difficult and there are no easy formulas for action. As academics and activists we should study these cases carefully and offer our support.

\section{References:}

Armbruster, Ralph (1997). "Cross-Border Labor Organizing in the Garment

Industry: The Struggle of Maquiladora Workers at Phillips Van-Heusen."

Paper presented at the Pacific Sociological Association Conference. 
Pattee, Jon (1996). "'Gapatistas' Win a Victory." Labor Research Review 24:

$77-86$

[Page 5]

Journal of World-Systems Research 